UDC 004.4:004.774.6CMS

\author{
S.V. Tytenko* \\ Igor Sikorsky Kyiv Polytechnic Institute, Kyiv, Ukraine \\ *corresponding author: lab@setlab.net
}

\title{
CONCEPT MAPS, THEIR APPLICATION TYPES AND METHODS IN INFORMATION AND LEARNING SYSTEMS
}

\begin{abstract}
Background. The hypermedia environment, which has received a powerful technical infrastructure thanks to the WWW, has led to the study and emergence of new forms and tools of information and educational content presentation. Various methods and means of visualization of educational information increase clarity and facilitate the process of new knowledge perception. Such tools include a wide range of concept maps that have become widespread in many areas related to information technology and education. The challenge here is to find comprehensive solutions that will reduce computing and labor costs for the multifunctional use of concept maps in information and learning systems.

Objective. The work is focused on the review of concept maps, research of preconditions for their origin, analysis of their types and purposes of application in the educational process and learning systems. The main task is to analyze the requirements for interactive concept maps in ontology-oriented information systems to support lifelong learning.

Methods. The use of concept maps in educational systems is based on knowledge modeling, graph theory, ontological modeling of educational content and methods of adaptive e-learning systems. The paper reviews and analyzes the application of concept maps and requirements for them within the information and learning systems.

Results. Concept maps have significant foundation in cognitive and educational psychology, computational linguistics, knowledge engineering and have widespread application in computer supported learning. Concept maps are used as a means of meaningful learning when constructed by students, used to assess knowledge, as well as a means of navigating information resources. Concept maps in educational systems are used to present knowledge to users and serve as interfaces in the process of exploratory search and review of study areas. Information systems provide enrichment of concept maps by means of interactivity, which allows diversifying and expanding its use.

Conclusions. The key requirements for interactive concept maps in information and learning systems are formed, including automation of interactive concept map construction, availability of wide navigation capabilities together with cognitive load control, implementation of interdisciplinary links, media annotation of map elements, complex application of graph interfaces for different parts of the system and adaptation to mobile devices.
\end{abstract}

Keywords: concept map; ontologies in education; educational systems; information and learning systems; e-learning; knowledge graph; conceptual graph; lifelong learning.

\section{Introduction}

Information and learning systems continue to play a significant role in educational processes of various forms. Such systems are in demand in school education, university programs, corporate education and professional self-development [1]. The hypermedia environment, which has received a powerful technical infrastructure thanks to the WWW, has led to the study and emergence of new forms and tools of information and educational content presentation. Various methods and means of visualization of educational information increase clarity and facilitate the process of new knowledge perception. Such tools include a wide range of concept maps that have become widespread in many areas related to information technology and education [2]. Concept map has the form of a graph, the nodes of which are the concepts of the subject area, and the edges correspond to the relationship between these concepts.
Such maps are first of all presented graphically on paper or digital media, and also are presented by means of formal mathematical apparatus.

\section{Problem Statement}

The work is focused on the review of concept maps, research of preconditions for their origin, analysis of their types and purposes of application in the educational process and learning systems. The main task is to analyze the requirements for interactive concept maps in ontology-oriented information systems to support lifelong learning.

\section{Graph and network representations and precon- ditions for the origin of concept maps}

The background for the emergence of concept maps of different types in the 1960's and 1970's were areas related to the psychology of learning, 
knowledge representation, cognitive psychology, linguistics, formal logic, natural language processing, and so on.

The early work on semantic networks is based on the work of Chomsky [3] in the field of linguistic structures and the work of many other researchers in psychological and cognitive linguistics. For example, Quillian [4] proposed a model of the semantic network based on studies of human memory modeling. The logical structure based on the sentences of natural language and the reasoning of such a system were visualized in the form of a graph based on the relations of associativity between concepts. The work gave impulse to the further relations specification and development of the formal apparatus of semantic networks (Fig. 1).

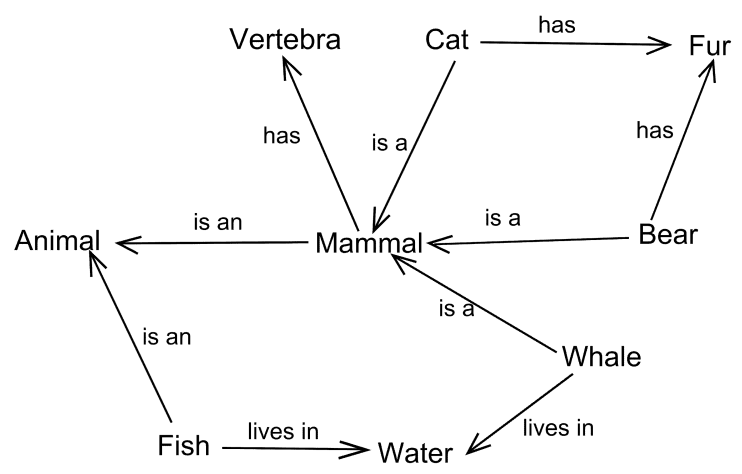

Fig. 1. Example of a semantic network [5]
In the field of pedagogical psychology Ausubel $[6,7]$ proposes concept of meaningful learning, based on the hypothesis that cognitive structures are organized hierarchically, where highly inclusive concepts contain less inclusive subordinate concepts and data. This means that for the successful assimilation of new learning material it must be incorporated into existing student's cognitive structures in such a way as to be subordinated and correlated with the relevant concepts already existing in the structure [7]. Thus, Ausubel emphasizes the importance of structuring and linking new information with existing information in the learning process [8]. Here it is proposed to implement these requirements with the help of advanced organizers, which are any form of visual, verbal or textual material that provides the structure of educational content. The main task of such organizers is to emphasize key concepts and their interconnections and relationships with known concepts [8].

These pedagogical and psychological foundations formed the basis for development of concept maps by Joseph D. Novak at Cornell University in 1972 [2]. Novak Maps are graphical tools for organizing and presenting relationships between concepts, represented by a line connecting two concepts. Words on a line are connection phrases that define the relationship between concepts. Concepts and propositions are usually organized hierarchically from the most general and most inclusive to the smallest [2] (Fig. 2). Such maps emerged as a means

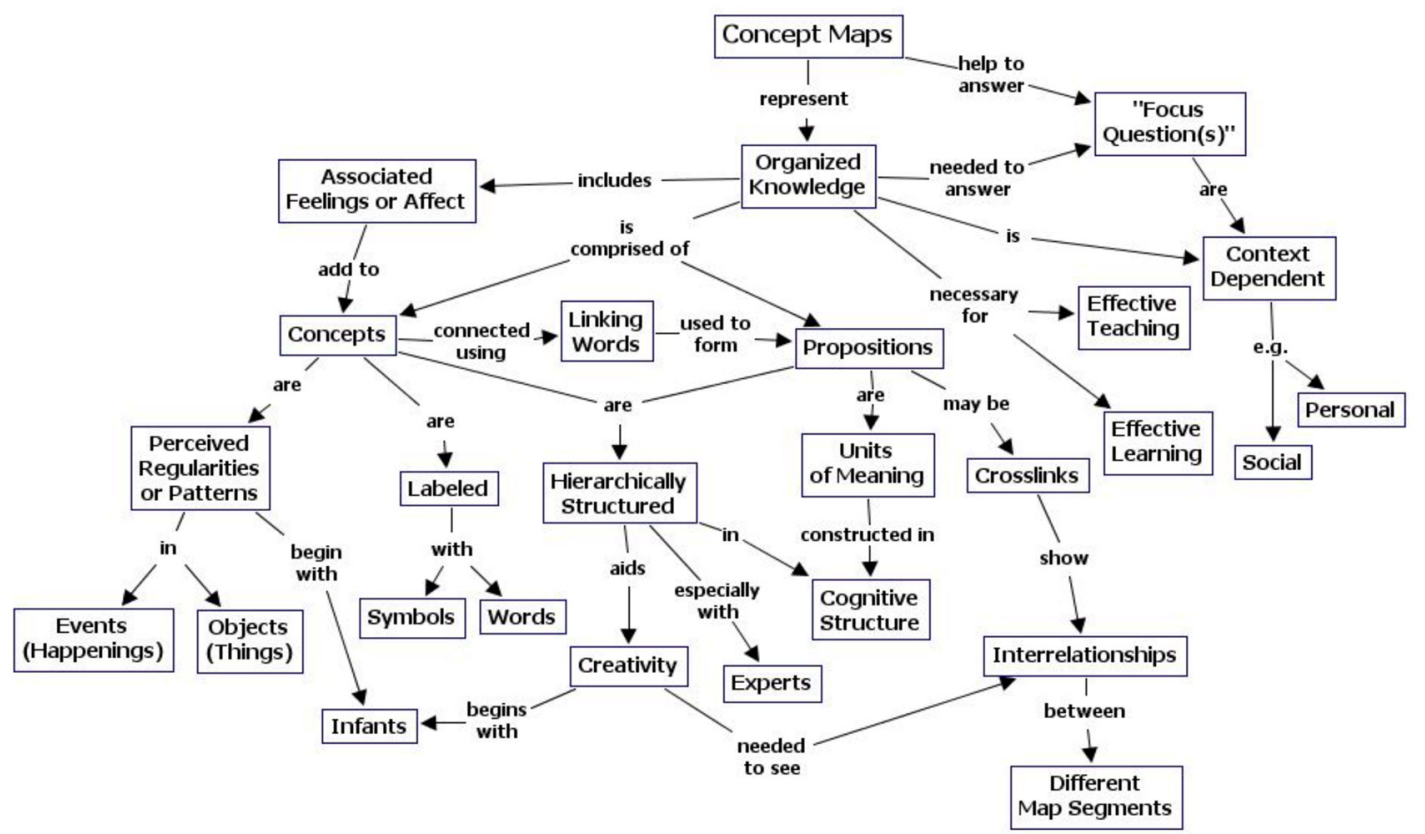

Fig. 2. Novak's concept map, which reveals the main features of concept maps [2] 
of implementing Ausubel's ideas to present new knowledge to students. The key application of Novak's maps is students' activity for concept map creation as a type of educational activity. Such maps help students structure their own propositions and correspond to the new information to what they already know, ensuring that new knowledge is assimilated into a personal cognitive structure. Concept maps and activities for their construction implement here meaningful learning according to Ausubel as opposed to rote learning. It should be emphasized that effective and clear concept maps according to Novak are built taking into account the correct focus on the consideration issue [2]. This means that each individual map does not aim to present all possible connections and dependent concepts, but instead presents the most important propositions in this learning context.

In 1976, Sowa introduced the conceptual graphs formalism [9], which he later described in detail in his book [10]. This book became a significant contribution to the field of knowledge representation. Conceptual graphs are a formal notation that mediates between a person and a computer. Graphs describe the meaning of data according to the user's point of view, but they are also associated with procedures that have access to data according to machine formalization [9]. An example of a conceptual graph is given in Fig. 3 [11]. Formally, a conceptual graph is a finite connected bipartite graph. Graph vertices represent concepts or conceptual relationships. Concepts are denoted by rectangles and relations by ellipses. Arc labels are not used here [13].

As noted in [12], the application of graphical knowledge representation, including use of conceptual graph theory, helps to formalize reasoning about the states, behavior and relationships of objects. Thus, several alternative hypotheses about complex objects and ambiguous situations can be created and studied, for example in the field of astronautics [12]. Researchers of NASA information systems [12] emphasize that such graphical knowledge representation helps the user to understand the domain area, simplifies the manipulation, editing and revision of knowledge and translate them into different levels of complexity for different audiences.

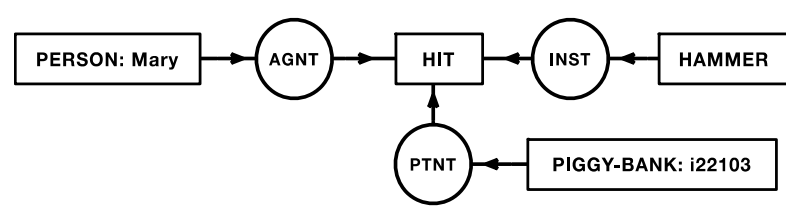

Fig. 3. Example of a conceptual graph [11]
In 1972, F. Dansereau and colleagues proposed a node-link mapping strategy as a continuation of the approach to using graphical charts for communication and the use of network models to conceptualize human memory [14]. Such maps are also called knowledge maps or Texas Christian University Node-Link Mapping (TCU-NLM). It is proposed to use three types of maps: information maps, guide maps and freestyle maps. Information maps (Fig. 4) are created by an expert in order to present a topic to students or end users. Guide maps are "fill-in-the-blank" graphic tools that could be used to solve problems or to support learning process. Freestyle maps are constructed by the student or user during the processing of verbal material to express the acquired knowledge [14]. Nodes are used to express concepts and features, connections (edges) have direction and are denoted by symbols, which correspond to the types of relations according to the legend.

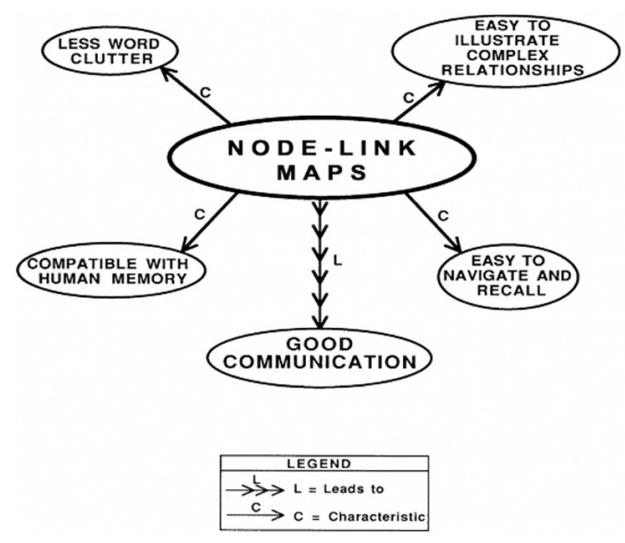

Fig. 4. An example of a node-link map [15]

TCU-NLM maps have shown effectiveness in learning process support, career counseling and business activities, in particular in conducting discussion meetings [14].

In 1974, Buzan in his book described the technique of mind maps [16]. He points out that the nature of mind maps is related to the work of the mind, and they can be used in almost any activity that involves thinking, memory, planning and creativity. Buzan proposed the use of mind maps for speech preparation, writing texts, problem analysis, for meetings and communication, as well as for notation [16].

A mind map is a diagram, in the center of which some concept is placed (Fig. 5). The form of the mind map is a radial tree, although in addition to hierarchical connections additional association edges between different elements of the structure 


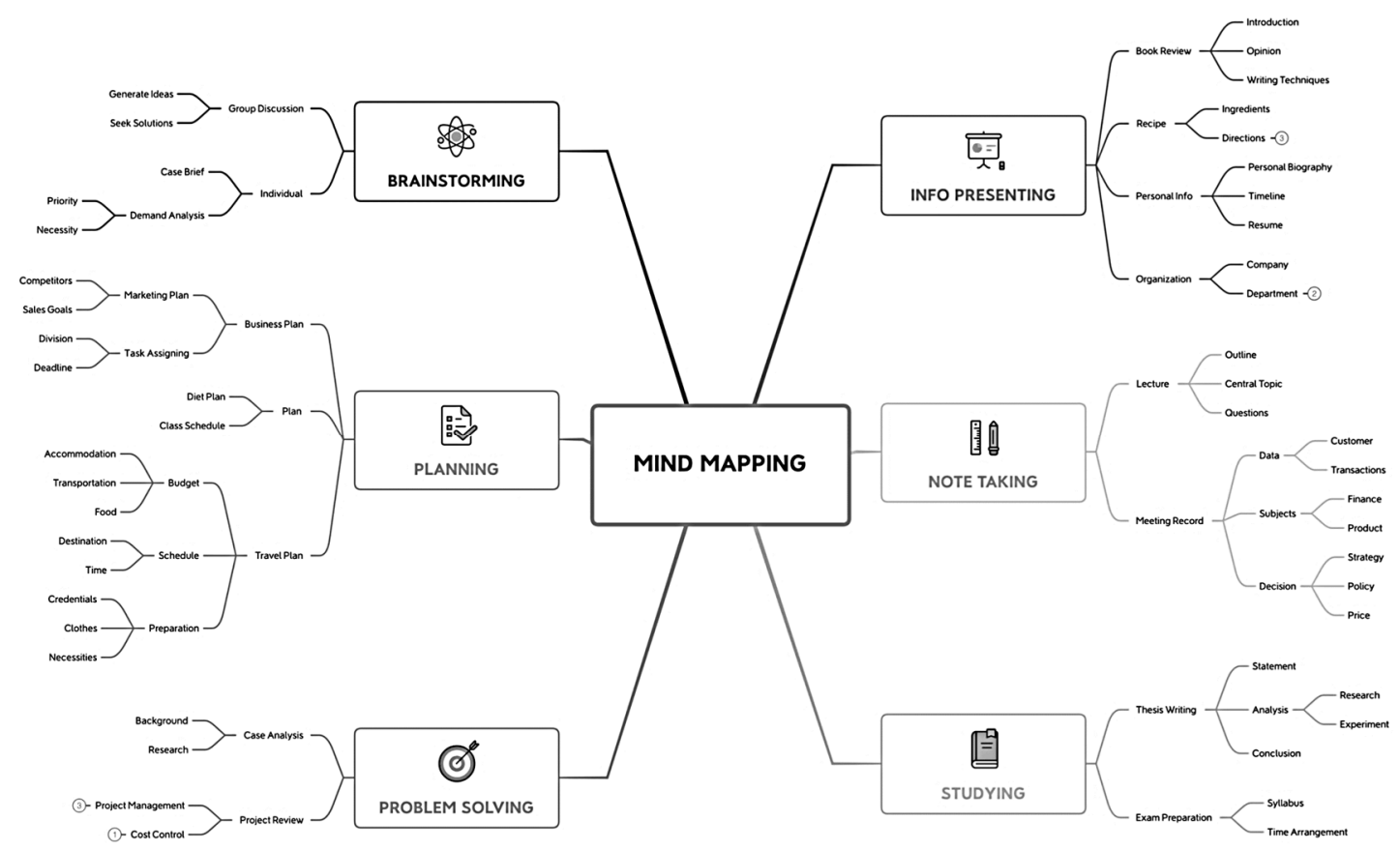

Fig. 5. Mind map example [18]

can also be used. Due to the radial form mind map became quite convenient for the presentation of information structures. Mind maps became widespread as a tool of idea visualization [17].

The rapid development of network representations and conceptual graph visualizations has led to wide research and practical interest in the use of concept maps in educational and information computer systems.

\section{Application of concept maps in information and learning systems}

Concept map construction by users. Novak emphasizes the effectiveness of constructing concept maps by students as a way to implement meaningful learning [2, 19]. Novak suggests using teaching methods that would encourage students to construct concept maps based on lectures and other learning materials [20]. Such activities encourage students to structure their own knowledge and gain deeper understanding of new material in relation to known data as opposed to rote learning. Information systems that allow the use of computer interfaces to create digital concept maps are seen as an important tool for the further implementation of such maps in educational systems [2].

Knowledge assessment. Researchers in [2, 21] point to successful examples of students' use of con- cept mapping techniques to assess knowledge. The map construction is thus effective in identifying both correct and incorrect student ideas. Concept maps can be just as effective as control interviews, which require a significant amount of time to identify the student's knowledge before and after the course [2]. Through self-assessment and concept map construction students can effectively identify and fix possible misconceptions.

Navigation in the learning environment. A significant amount of research is focused on the use of concept maps to improve navigation in the hypermedia environment of educational systems [2, 2224]. Puntambekar pays considerable attention to nonlinear navigation in educational hypermedia systems [22]. The advantage of hypertext learning systems is the ability to present content in a way that reflects many interrelationships between concepts [22]. Using concept maps for this purpose is a convenient mechanism. Concept maps can be hierarchical, which illustrates the structure of the study field, and non-hierarchical, which allows one to represent multiple relations [22, 25]. In [23] it is proposed to use navigation using concept maps for self-directed learning and for community-based learning. The standard of topic maps ISO [26] for Multi-layer Map Model of educational resources is used here [23]. It is noted that the use of visualizations based on topic maps, helped students find the 
necessary learning resources faster, helped to organize learning resources more meaningfully, and also contributed to more effective resource selection within learning communities [23]. Eldefrawi [24] suggests the use of concept maps to navigate Wikipedia's encyclopedic data. Emphasis is placed on information overload when navigating encyclopedia resources only by regular methods of the system based on hyperlinks in articles and categories. Instead, concept maps that represent the domain area can facilitate this process [24].

Knowledge presentation to users. Authors in [2, 27] suggest the use of concept maps for convenient content presentation. Such concept maps help user to quickly determine the relevance of documents to their own information needs. Concept maps for presenting content of documents help user to better understand key concepts and semantic structure of the document and become a kind of index that helps in further work with the document [27]. Concept map allows one to present information in a compact and easy to understand format, and is an effective means of summarizing documents. Such summary maps of the document in combination with hyperlinks can serve as a convenient interface for navigating to required areas of the document [27].

Exploratory search. More specific kind of content representation in exploratory search deserves special attention. The technique of exploratory search in many information and educational resources involves such comprehensive information retrieval activities, which include analysis of many information sources and determining the relevant direction of further research. Such activities are relevant for lifelong learning and self-development of experts. Exploratory search requires the latest human-machine interfaces to increase speed of user resource analysis and decision making on further movement through information resources. [28, 29] suggest the use of concept maps for exploratory search. Sarrafzadeh [29] uses hierarchical and nonhierarchical concept graphs to present search results. Falke [28] offers automated text annotation in the form of concept maps and their use in interfaces of the exploratory search system.

Interactive concept maps. In previous works also the use of interactive concept maps in the learning environment is proposed $[17,30]$. Here we offer a system interface that implements a concept map in the form of an interactive graph with the functions of scaling, finding concepts on the graph, navigation and processing of user interaction with visualized objects. The function of displaying of aggregate text and media information about the conceptvertex in the graph is given that is based on the display of the corresponding concept theses [17, 30] (Fig. 6). Proposed semantic portal [30] uses interactive maps to present the content of sections and individual articles in the form of graphs that show content structure and contain hyperlinks to relevant sections.

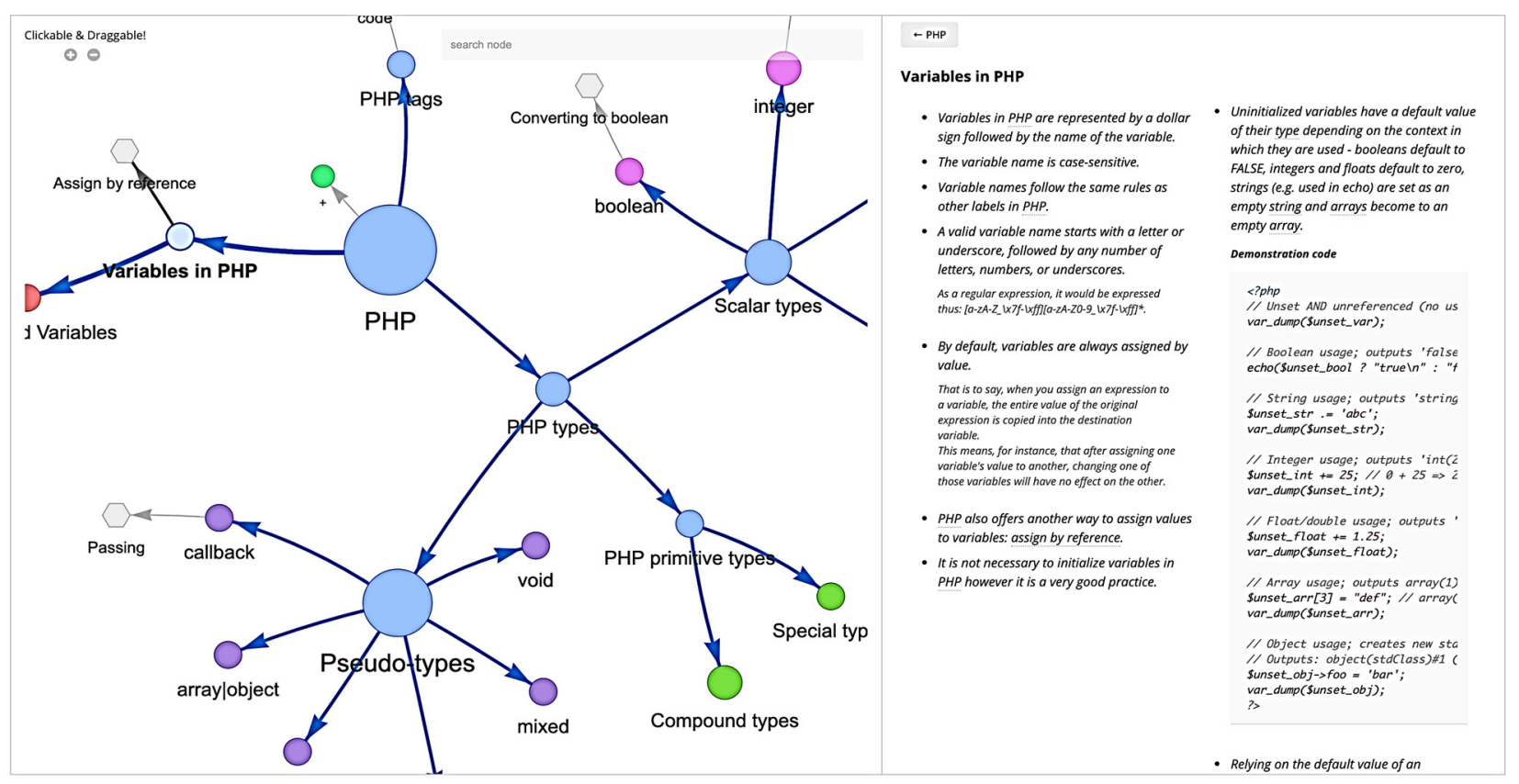

Fig. 6. Interactive concept map [17, 30] 
Handler [31] proposes to apply interactivity to concept maps in a digital learning environment. In particular, it is proposed to provide text explanations for the edges-relationships between concepts in a response to the corresponding user manipulations with the concept map. Hwang [32] considers the approach to the use of interactive concept maps in the educational process, which are constructed by students using mobile devices. The interface of the system provides the possibility of feedback, commenting on maps, additional information for the maps, indicating the relevant training materials. The work with maps on mobile devices should provide appropriate user interfaces that will provide convenient performance of interactive functions and map view, taking into account the features and limitations of gadgets. Authors in [33] propose the use of interactive concept maps to access collections of information resources in digital libraries for educational purposes. Such interfaces help users stay focused on scientific content that is relevant to their research goal and less distracted by the technical aspects of search [33].

Comprehensive solutions. Novak [2] expressed the idea of a learning environment with a wide application of concept maps. Great scientific and practical interest determines the relevance of educational system development with widespread use of concept maps for educational information presentation, navigation in the learning environment, information retrieval in concept maps and related resources, exploration of the domain area, interdisciplinary integration, collaboration and presentation of own research of study field. In [17, 30] we present an attempt to develop a comprehensive approach to the use of concept maps in an ontology-oriented information and learning portal. Automated construction of concept maps is integrated with methods of semantic content formalization, concept maps support navigation through educational resources and the use of text-media annotation of vertices based on an interactive interface $[17,30]$. The task of automated concept map construction for integrated multifaceted solutions in e-learning systems remains a meaningful and relevant task.

Requirements for modern interactive concept maps in information and learning systems

Based on previous research [1] and taking into account the effectiveness of concept maps to solve various educational problems, it is proposed to develop the use of concept maps in ontology-oriented information and learning systems, focusing on finding comprehensive solutions to optimize labor and computing costs. Based on the review, the following requirements for interactive concept maps in information and learning systems are formulated.

Automation of interactive concept map construction. Much attention is paid to automating of concept map construction [28, 31]. Instead, attempts to automatically construct summary maps based on text have limitations and require an additional search for a balance of automatic processing and editing by an expert in order to achieve the optimal didactic adequacy. In a previous work [17] a comprehensive solution for the content formalization was proposed, which has a multifunctional application for the learning system, including the automated construction of interactive concept maps. This approach is considered promising in terms of balance of labor cost and didactic relevance.

Availability of wide navigation capabilities and reduction of cognitive load. The analysis presented above shows the great potential of concept maps for the implementation of concept-oriented navigation of educational resources. At the same time, conceptualization of large amounts of information and educational content involves significant cognitive load when using appropriate graph visualizations. It is important to find effective mechanisms for contextualized display of fragments of conceptual graphs, which will reduce the information overload of maps and with the help of interactive interface tools will provide opportunities for further detailing and diving into the subject area by displaying appropriate subgraphs and branches.

Implementation of interdisciplinary relations. In [1], we noted the importance of developing and using interdisciplinary connections in information and learning systems that aim to support lifelong learning. Concept maps are a visual method of visualizing relationships, including interdisciplinary ones. Instead, the challenge here is the difference of terminological contexts in educational resources from different subject areas and the ambiguity of terms in their interdisciplinary application. Concept maps applied to multidisciplinary information and educational repositories should address this problem accordingly.

Natural language and media annotation of map elements, including description of vertices and edges. $[2,23]$ and other works propose and describe the function of map interactivity, which provides a navigational connection between the graph view and media and text content, which provide explanations 
of the concept or structure. Such functionality significantly expands the possibilities of educational content presentation using concept maps. The annotated description of the edges in [31] is a didactically significant technique that will help users to analyze the concepts in relation to each other. The widespread use of interactive content support the graph structure in our work [17, 30] has demonstrated its practical usefulness and confirms the relevance of the development of such functionality in interactive concept maps.

Integrated application of graph interfaces and concept maps in interactive learning environments. The effectiveness of displaying complex conceptual structures and propositions in the form of graph visualizations has led to the popularity and versatility of the use of concept maps in the field of educational information systems. On the other hand, the features and established forms of hypermedia content, as well as the professional field that explores user experience (UI/UX), together form a challenge to find effective formats for the wide use of interactive concept maps in information and learning systems. We are talking not only about the conceptual presentation of content areas, but also the wider use of concept maps as interface solutions for navigating information and learning resources. Thus, in the developed web portal [30] we try to provide alternatives to the standard hypertext ways of reviewing the structure of the course and individual pages in the form of graphs, which nodes represent sections and parts of content and are effective hyperlinks to these sections.

Interfaces adaptation to mobile devices. There is a clear trend towards the predominant use of mo- bile devices compared to desktop computers [34]. This causes the urgency of adapting the interfaces of information and learning systems to the software and hardware capabilities of smartphones. In [32] attention is paid to the peculiarities of the organization of the interface when constructing a concept map using a mobile device. The use of interactive concept maps within mobile systems is a significant challenge in terms of UI/UX and determines the search for optimal solutions to ensure convenient human-machine interaction.

\section{Conclusions}

The paper reviews the preconditions for the emergence of concept maps, reviews their types and applications in the educational process and learning systems. It is showed that concept maps have significant foundation in cognitive and educational psychology, computational linguistics, knowledge engineering and have widespread application in computer supported learning.

Based on the analysis, the key requirements for interactive concept maps in modern information and educational systems are formed, including automation of interactive concept map construction, availability of wide navigation capabilities together with cognitive load control, implementation of interdisciplinary links, media annotation of map elements, complex application of graph interfaces for different parts of the system and adaptation to mobile devices. The current implementation of interactive maps, which follows the outlined requirements, is presented on the resource [30] and is described in [17].

\section{References}

[1] O. Gagarin and S. Tytenko, "Research and analysis of methods and models of lifelong learning intelligent systems", Research Bulletin NTUU “KPI”, vol. 6, no. 56, pp. 37-48, 2007.

[2] J.D. Novak and A.J. Cañas, "Theoretical origins of concept maps, how to construct them, and uses in education", Refl. Educ., vol. 3, no. 1, pp. 29-42, 2007.

[3] N. Chomsky, Aspects of the theory of syntax. Cambridge, MA: M.I.T. Press, 1965.

[4] M.R. Quillian, "Word concepts: A theory and simulation of some basic semantic capabilities", Behav. Sci., vol. 12, no. 5, pp. 410-430, 1967. doi: 10.1002/bs.3830120511

[5] Example of a semantic network. [Online]. Available: https://en.wikipedia.org/wiki/Semantic_network\#/media/File:Semantic_Net.svg

[6] D.P. Ausubel, The Psychology of Meaningful Verbal Learning. New York: Grune \& Stratton, 1963.

[7] D.P. Ausubel, "The use of advance organizers in the learning and retention of meaningful verbal material", J. Educ. Psych., vol. 51, no. 5, pp. 267-272, 1960. doi: 10.1037/h0046669

[8] A.P. Johnson, Essential Learning Theories: Applications to Authentic Teaching Situations. Rowman \& Littlefield, 2019.

[9] J.F. Sowa, "Conceptual graphs for a data base interface", IBM J. Res. Developm., vol. 20, no. 4, pp. 336-357, 1976. doi: $10.1147 /$ rd.204.0336

[10] J.F. Sowa, Conceptual structures: Information processing in mind and machine. Reading, MA: Addison-Wesley, 1984. 
[11] J.F. Sowa, "Semantics of conceptual graphs," in Proc. 17th annual meeting on Association for Computational Linguistics, 1979 , pp. 39-44. doi: 10.3115/982163.982175

[12] D.R. Corbett and C. Rouff, "Self optimization using conceptual graphs for NASA autonomous systems," in Proc. Third IEEE International Workshop on Engineering of Autonomic \& Autonomous Systems (EASE'06), 2006. doi: 10.1109/EASE.2006.11

[13] G.F. Luger, Artificial Intelligence: Structures and Strategies for Complex Problem Solving, 5th ed. Pearson, 2005.

[14] D.F. Dansereau, "Node-link mapping principles for visualizing knowledge and information," in Knowledge and Information Visualization. Lecture Notes in Computer Science, vol. 3426, S-O. Tegran and T. Keller, Eds. Berlin, Heidelberg: Springer, 2005, pp. 61-81. doi: 10.1007/11510154_4

[15] D.F. Dansereau et al. (1993). Mapping new roads to recovery. A self-paced training manual designed for substance abuse counselors and case workers interested in node-link mapping [Online]. Available: https://core.ac.uk/download/pdf/34718088.pdf

[16] T. Buzan, Using both sides of the brain. New York: E.P. Dutton, 1974.

[17] S.V. Tytenko, "Interactive concept maps in ontology-oriented information and learning web-systems", KPI Sci. News, no. 2, pp. 24-36, 2019. doi: 10.20535/kpi-sn.2019.2.167515

[18] Mindmap sample [Online]. Available: https://assets.xmind.net/www/assets/images/home/home-hero-ui@3x-64881d8d06.png

[19] J.D. Novak, "Concept maps and Vee diagrams: Two metacognitive tools for science and mathematics education", Instr. Sci., vol. 19, no. 1, pp. 29-52, 1990. doi: 10.1007/BF00377984

[20] J.C. Nesbit and O.O. Adesope, "Learning with concept and knowledge maps: A meta-analysis", Rev. Educ. Res., vol. 76, no. 3, pp. 413-448, 2006. doi: 10.3102/00346543076003413

[21] I.M. Kinchin et al., "Uncovering types of knowledge in concept maps", Educ. Sci., vol. 9, no. 2, p. 131 , 2019. doi: 10.3390/educsci9020131

[22] S. Puntambekar et al., "Improving navigation and learning in hypertext environments with navigable concept maps", HumanComput. Interact., vol. 18, no. 4, pp. 395-428, 2003. doi: 10.1207/s15327051hci1804_3

[23] H. Li et al., "A multi-layer map-oriented resource organization system for web-based self-directed learning combined with community-based learning”, Res. Pract. Technol. Enhanc. Learn., vol. 10, no. 1, 2015. doi: 10. 10.1186/s41039-015-0012-2

[24] M. Eldefrawi et al., "Bootstrapping domain knowledge exploration using conceptual mapping of Wikipedia", Int. J. Advanc. Comput. Sci. Applicat., vol. 4, no. 8, 2013. doi: 10.14569/IJACSA.2013.040813

[25] R.J. Shavelson et al., "On concept maps as potential "authentic" assessments in Science” CRESST, UCLA, Los Angeles, CA, CSE Techn. Rep. 388, Aug. 1994.

[26] Topic Maps, ISO/IEC 13250, 2002.

[27] A. Valerio et al., "Using automatically generated concept maps for document understanding: A human subjects experiment," in Fifth International Conf. on Concept Mapping, Valetta, Malta, 2012, pp. 438-445.

[28] T. Falke. "Automatic structured text summarization with concept maps," Ph.D dissertation, Technische Universität Darmstadt, Hessen, Deutschland, 2019.

[29] B. Sarrafzadeh and E. Lank, "Improving exploratory search experience through hierarchical knowledge graphs," in Proc. 40th International ACM SIGIR Conf. on Research and Development in Information Retrieval, 2017, pp. 145-154. doi: $10.1145 / 3077136.3080829$

[30] Semantic Portal [Online]. Available: http://semantic-portal.net

[31] A. Handler et al., "Summarizing relationships for interactive concept map browsers," in Proc. of the 2nd Workshop on New Frontiers in Summarization, 2019, pp. 111-115. doi: 10.18653/v1/D19-5414

[32] Gw-J. Hwang et al., "An interactive concept map approach to supporting mobile learning activities for natural science courses”, Comput. \& Educ., vol. 57, no. 4, pp. 2272-2280, 2011. doi: 10.1016/j.compedu.2011.06.011

[33] T. Sumner et al., "Linking learning goals and educational resources through interactive concept map visualizations", Int. J. Digit. Librar., vol. 5, no. 1, pp. 18-24. 2005. doi: 10.1007/s00799-004-0112-x

[34] M. Roser et al. (2015). Internet [Online]. Available: https://ourworldindata.org/internet

\section{С.В. Титенко}

\section{КАРТИ ПОНЯТЬ, ЇХ ВИДИ ТА МЕТОДИ ЗАСТОСУВАННЯ В ІНФОРМАЦІЙНО-НАВЧАЛЬНИХ СИСТЕМАХ}

Проблематика. Гіпермедіа-середовище, що отримало потужну технічну інфрраструктуру завдяки WWW, зумовило дослідження та появу нових форм і засобів презентації інформаційно-навчального контенту. Різноманітні методи та засоби візуалізації навчальної інформації підвищують наочність і полегшують процес засвоєння нових знань. Серед таких засобів - широка палітра концептуальних карт, що набули значного поширення в багатьох галузях, суміжних з інформаційними технологіями й освітою. Викликом тут $є$ пошук комплексних рішень, що дадуть змогу зменшити обчислювальні та трудові витрати на багатофункціональне застосування карт понять в інформаційно-навчальних системах. 
Мета дослідження. Дослідити передумови створення карт понять, проаналізувати їх типи та цілі застосування в навчальному процесі й інформаційно-навчальних системах. Описати вимоги до інтерактивних карт понять в онтологічно орієнтованих системах для підтримки безперервного навчання.

Методика реалізації. Використання карт понять в освітніх системах базується на моделюванні знань, теорії графів, онтологічному моделюванні навчального контенту та методах адаптивних систем електронного навчання. У статті проаналізовано застосування карт понять і вимоги до них в інформаційно-навчальних системах.

Результати дослідження. Карти понять спираються на значущі підвалини когнітивної та педагогічної психології, комп'ютерної лінгвістики, інженерії знань й отримали широке застосування в електронному навчанні. Карти понять використовуються як засіб осмисленого навчання при їх конструюванні учнями, застосовуються для оцінювання знань, а також як засоби навігації інформаційними ресурсами. Карти понять у навчальних системах використовуються для презентації знань користувачам, $є$ інтерфейсами в дослідницькому пошуку та огляді предметних областей навчання. Інформаційні системи забезпечують збагачення карт понять засобами інтерактивності, що дає можливість диверсифікувати та розширити їх використання.

Висновки. Сформовано ключові вимоги до інтерактивних карт понять у сучасних інформаційно-навчальних системах, що включають автоматизацію побудови інтерактивних карт понять, наявність широких навігаційних можливостей разом із контролем когнітивного навантаження, реалізацію міжпредметних зв'язків, медійне анотування елементів карти, комплексне застосування графових інтерфейсів для різних частин системи та адаптацію до мобільних пристроїв.

Ключові слова: карта понять; онтології в освіті; навчальні системи; інформаційно-навчальні системи; електронне навчання; граф знань; концептуальний граф; безперервне навчання.

\section{С.В. Титенко}

\section{КАРТЫ ПОНЯТИЙ, ИХ ВИДЫ И МЕТОДЫ ПРИМЕНЕНИЯ В ИНФОРМАЦИОННО-ОБУЧАЮЩИХ СИСТЕМАХ}

Проблематика. Гипермедиа-среда, получившая мощную техническую инфраструктуру благодаря WWW, обусловила исследования и появление новых форм и средств презентации информационно-учебного контента. Различные методы и средства визуализации учебной информации повышают наглядность и облегчают процесс восприятия новых знаний. Среди таких средств широкая палитра концептуальных карт, получивших широкое распространение во многих областях, смежных с информационными технологиями и образованием. Вызовом здесь является поиск комплексных решений, которые позволят уменьшить вычислительные и трудовые затраты на многофункциональное применение карт понятий в информационно-обучающих системах.

Цель исследования. Исследовать предпосылки к созданию карт понятий, проанализировать их типы, цели применения в учебном процессе и информационно-обучающих системах. Описать требования к интерактивным картам понятий в онтологическиориентированных системах для поддержки непрерывного обучения.

Методика реализации. Использование карт понятий в образовательных системах базируется на моделировании знаний, теории графов, онтологическом моделировании учебного контента и методах адаптивных систем электронного обучения. В статье проанализировано применение карт понятий и требования к ним в информационно-обучающих системах

Результаты исследования. Карты понятий опираются на значимые основы когнитивной и педагогической психологии, компьютерной лингвистики, инженерии знаний и получили широкое применение в электронном обучении. Карты понятий используются как средство осмысленного обучения при их конструировании учениками, применяются для оценки знаний, а также как средства навигации по информационным ресурсам. Карты понятий в учебных системах используются для презентации знаний пользователям, служат как интерфейсы в процессе исследовательского поиска и обзора предметных областей обучения. Информационные системы обеспечивают обогащение карт понятий средствами интерактивности, что позволяет диверсифицировать и расширить их использование.

Выводы. Сформированы ключевые требования к интерактивным картам понятий в современных информационно-обучающих системах, включающие автоматизацию построения интерактивных карт понятий, наличие широких навигационных возможностей вместе с контролем когнитивной нагрузки, реализацию межпредметных связей, медийное аннотирование элементов карты, комплексное применение графовых интерфейсов для различных частей системы и адаптацию к мобильным устройствам.

Ключевые слова: карта понятий; онтологии в образовании; обучающие системы; информационно-обучающие системы; электронное обучение; граф знаний; концептуальный граф; непрерывное обучение.

Рекомендована Радою

теплоенергетичного факультету

КПІ ім. Ігоря Сікорського
Надійшла до редакції 13 серпня 2020 року

Прийнята до публікації 10 грудня 2020 року 